\title{
On Cultivating Intercultural Critical Thinking Ability in English Teaching for Non-English Major Graduates*
}

\author{
CHEN Jing-xia \\ Central University of Finance and Economics, Beijing, China
}

\begin{abstract}
After discussing the important concepts that guide English teaching in universities in China, the author draws a roadmap of Language and Intercultural Critical Thinking Integrated Approach (LICTIA) for English teaching for non-English major graduates in Central University of Finance and Economics, and then expounds on the particulars concerning the application of LICTIA in English classes. English teaching for non-English major graduates aims to cultivate graduates' global competence and intercultural critical thinking ability besides the improved language skills.
\end{abstract}

Keywords: LICTIA, global competence, intercultural critical thinking, language skills

\section{Introduction}

Foreign language education in China set by Higher Education Division of Ministry of Education in 2007 aims to improve students' comprehensive language abilities and accomplish the humanistic education as well (Wen, 2015, p. 550). On 12, April, 2018, Ministry of Education of the People’s Republic of China and National Language Commission of the People's Republic of China released China's Standards of English Language Ability (CSE) in both Chinese and English versions. As the "Scope" in the CSE reads, "the CSE defines the levels of English ability of Chinese learners and users of English, and describes the features of their English language ability at each CSE level” (p. 1), the CSE can be used as a yardstick for English teaching and learning and be applied to English assessment. Besides the acquisition of language skills, intercultural critical thinking is also an important ability for English learners and users as well. Sun Youzhong (2017) proposed liberal English education (LEE) as a new paradigm for English teaching in China, which intends for an integrated study of language and knowledge, building a community for language learners and simultaneously improving their language abilities, critical thinking, intercultural competence, and humanistic quality (p. 859).

With these in mind, I have found Language and Intercultural Critical Thinking Integrated Approach (LICTIA) an effective and practical pedagogy to cultivate students' global competence and intercultural critical thinking ability. When I worked on two units of the textbook Critical Listening, Book IV to be published by Beijing Foreign Language Teaching and Researching Press in July 2019, I attended several seminars on how to cultivate critical thinking ability and conducted researches in this area, and started to think about ways to develop students' global competence and intercultural critical thinking ability in non-English major graduates’

\footnotetext{
* Acknowledgement: This work was supported by a grant from “Fundamental Research Funds for the Central Universities” and a grant from "Research Supporting Program of Schools of Central University of Finance and Economics” (011650314014/010).

CHEN Jing-xia, Ph.D., associate professor, School of Foreign Studies, Central University of Finance and Economics, Beijing, China.
} 
English classes at Central University of Finance and Economics. I also draw on my teaching experience of English and American Literature and English Listening with the English majors in their undergraduate program. Up till now, I have been teaching graduates for a couple of years, and I have been constantly innovating the teaching methods and capitalizing on advanced pedagogy, as I am not satisfied with the old idea that prioritizes language skills in English learning. This paper first discusses some important concepts that drive innovation in English teaching and draws a roadmap of LICITA in the graduates' English class and then expounds on the application of LICITA.

\section{A Roadmap of Language and Intercultural Critical Thinking Integrated Approach}

Several important concepts are essential to English teaching in Chinese universities. They are global competence, critical thinking, and intercultural competence. They become the set goals of English teaching. The following is the itemitization of the concepts.

In 2016, Organization for Economic Cooperation and Development (OECD) defined global competence as the capacity to analyze global and intercultural issues critically and from multiple perspectives, to understand how differences affect perceptions, judgements, and ideas of self and others, and to engage in open, appropriate and effective interactions with others from different backgrounds on the basis of a shared respect for human dignity, and stated that it was an important competence for students to acquire. Students I teach in the 2018-2019 semester major in Finance, Accounting, Industries, National Economy, etc. Many of them will have the chance to work in a multi-cultural environment. Therefore, it is essential for them to cultivate global competence.

Dr. Richard Paul and Dr. Linda Elder (2006) defined critical thinking as "the art of analyzing and evaluating thinking with a view to improving it” (p. 4). Critical thinking is, in short,

self-directed, self-disciplined, self-monitored, and self-corrective thinking. It requires rigorous standards of excellence and mindful command of their use. It entails effective communication and problem-solving abilities and a commitment to overcome our native egocentrism and sociocentrism. (p. 4)

Intercultural competence is

a range of cognitive, affective, and behavioral skills that lead to communicating effectively and appropriately with people of other cultures. Appropriate intercultural communication includes behaviors that suit the expectations of a specific culture, the characteristics of the situation, and the level of the relationship between the communicators. ${ }^{1}$

Concomitantly, these concepts stress the importance to transcend one's own culture and overcome one's native egocentrism in order to accomplish effective communication with people from other cultures. As globalization deepens, this capability becomes increasingly essential because "cultural diversity is as necessary for humankind as biodiversity is for nature” (UNESCO, 2001). This becomes an integral part of language learning, and the cultivation of the capability should be complemented at the stage of higher education.

Language and Intercultural Critical Thinking Integrated Approach facilitates the realization of the goal. It integrates the acquisition of language skills with content learning and simultaneously improves language users' language ability, intercultural critical thinking, and humanistic education. A variety of class activities are conducted to achieve the objectives. They include exploratory task, interpretive task, reflective task, evaluative

1 “Intercultural Competence”, July 17th 2017 <https://en.wikipedia.org/wiki/Intercultural_competence>. 
task in the form of debate, case analysis, public speech, panel discussion, role-playing, and pair work, etc.

Through these activities, language users try to develop the intellectual traits or virtues: intellectual humility, intellectual autonomy, intellectual faith/integrity, intellectual courage, intellectual perseverance, confidence in reason, intellectual empathy, and fairmindedness (Paul \& Elder, 2006, p. 20). They are important for intercultural communication.

In the course introduction class, I brief students with the roadmap of LICITA. Informing the students of the approach, the course objectives and the schedule is of vital importance as they can be more actively involved in class activities when they are clear of the purposes.

In the next section, I am going to expound on the application of LICTIA in the graduates' English classes.

\section{The Application of LICTIA in the Graduates' English Classes}

Intercultural critical thinking is developed in integration with the cultivation of language skills. Reading and listening are taught every odd week; listening and speaking are taught every even week. I am very careful with the selection of reading and listening materials. They have to be multifarious, up-dated, and value-focused.

The reading materials cover literary work, argumentative writing, and book review so that students can experience the different style of writing. They are Doris Lessing's initiation story "Through the Tunnel" and her Nobel Lecture, Edward Koch's "Death and Justice” and a book review on two of Winston Churchill's biographies_-"Winston Churchill's Other Lives”. Each reading material has a focus. "Through the Tunnel” aims to introduce students to the subgenre of coming-of-age story and encourage them to understand the story in the context of Britain's reconstruction in the postwar years and in the postcolonial context as well. Students are required to write a responsive paper. "Death and Justice" intends to teach students how to develop an argument and how to employ various methods to support the argument. Students are asked to write an argumentative writing on a certain topic and conduct a debate. "Winston Churchill's Other Lives" introduces students to the basic elements of a book review and enables them to understand the importance of book reviews in their research work. They are asked to write a book review on a book that is related to their majors.

Listening materials are topic-related, covering the hot issues in politics, culture, society, finance and economics, and economic phenomenon/climate, etc. The topics include American presidency, which focuses on three American presidents-Abraham Lincoln, Barack Obama, and Donald Trump-and the American ideals; business in Africa, which attracts the world attention when Sino-African cooperation forum was held in Sept. 2018; and other materials concerning the empowerment of art, women's status, and protectionism and globalization when the trade dispute between China and America accelerated. These topics are chosen to encourage students to walk out of the ivory tower and to speculate on things that are important to the globe. In teaching, students are encouraged to read and listen to various materials and to establish schemata, which help to improve their four language skills.

\section{Reading and Writing Activities}

Northrop Frye remarks that "literary education is not doing the whole of its proper work unless it marshals the verbal imagination against the assaults of advertising and propaganda that try to bludgeon us into passivity" (as cited in Jewkes, 1976, p. 281). Reading literary work can help students alter their mental habits. As a literary teacher, I have always seen how literary works have transformed the students in one way or another. I firmly believe that literature can be effectively used to cultivate students' language sensitivity, empathy, 
imagination, and critical thinking. Besides, values education or values clarification can be infused into literature teaching, for "inherent in the study of literature is the study of values—values clashing, shifting, failing" (McClaran, 1978, p. 56):

Values clarification improves students' self concepts, aids in understanding interpersonal relationships, and forms the foundation for decision-making. These concepts have undergirded English teaching all along; in fact, values education may have always been the most important facet of secondary language studies.

Therefore, I encourage the non-English majors to read literary classics and to read with a healthy skepticism.

Doris Lessing's “Through the Tunnel”, published in 1955 on the New Yorker magazine, focuses on an 11-year-old English boy Jerry's growth and transformation while vacationing with his widowed mother in a summer resort, who is anxious neither to be overprotective nor negligent toward her son. After encountering a group of local boys, Jerry wants to swim through the tunnel, a rite that marks his independence from his mother. Students feel personally related to the work, because they all had such an eagerness for growth and independence during their adolescence. Reading this story enables them to understand what an initiation story is and to identify the epiphany in the story. What is more important, I direct students' attention to the historical context of the story and lead them to understand the work in the context of the collapse of the British Empire and its post-war reconstruction. Therefore, they can understand the anxiety and difficulty of a single mother to raise a child alone in the post-war years. The introduction to some of the important concepts in Edward Said's Orientalism helps them figure out how the description of the landscape is ideologically tainted and how the narrator excludes the native boys from the narrative and uses them as a benchmark for the English boy's growth. Students then mark out the racial bias or preconceptions embodied in the story. Students are also required to write a reaction paper on the story. They cover various topics in their writing: How to get along with their parents, how to get out of the comfort zone, and how to grow through frustrations in life. This retrospective point of view facilitates a better self-knowledge.

Argumentative writing helps students to take a comprehensive view and get rid of biases, distortion, partiality, ignorance, and down-right prejudice. Edward Koch’s "Death and Justice” concerns a controversial topic: Should death penalty be reinstated as an effective way to root out heinous crimes? This clear-cut article is an exemplary writing on how to make an effective argument and develop it convincingly. The writer employs various methods to develop his points, such as analogy, comparison, contrast, citation of authoritative views, statistics, and cases. The most impressive feature of the writing is the effective organization of the article: The writer presents significant objections and counterevidence and then adequately discusses them; therefore, by refuting the cons of capital punishment, the writer convinces the reader that death penalty is the only effective means to guarantee social justice and protect the precious lives.

While analyzing the article, I ask students to consider the question: What appeals does the author make? I introduce them to the ancient Greek philosopher Aristotle's exposition of classical Persuasion in his The Art of Rhetoric, in which Aristotle emphasizes that a successful speech must comprise "ethos, logos, and pathos” to be effective and convincing. "Ethos”, meaning personality in Greek, requires the speaker to get the audience's trust and confidence by presenting his knowledge and morality. "Pathos", originating in Greek, means "to suffer, endure”. It refers to the emotional appeal in Rhetoric. "Logos” refers to rational appeal, by relying on the logic and causality of language. Therefore, the previous question can be broken down into three questions: 
Does the author appeal to reason (logos), for instance, with statistics, the testimony of authorities, and personal experience? To emotions (pathos), for instance, by an appeal to "our better nature", or to widely shared values? To our sense that the speaker is trustworthy (ethos)? By figuring out the answers, students learn how to write an effective argumentative writing.

Practice can consolidate students' command of the argumentative writing. In practice, students are divided into six groups and each group is assigned a topic. The following questions contain the pros and cons of the topics:

1. Should a mother stay at home to raise a child? Or not?

2. Are you for or against human microchip implant?

3. Which should be the future for the world: protectionism or globalization?

Each student is required to write an essay as the preliminary work for debates. Then, they bring their writings in class and have a group discussion to prepare for the debate. Each student contributes a lot to the activity, although only four students represent the group to take part in the final debate. Through reading, writing, and debating, students learn to question information, conclusions, and points of view; they learn to be clear, accurate, precise, and relevant; and they learn to think beneath the surface, and to be logic and fair.

Another type of reading is a book review, aiming to teach students how to summarize, how to evaluate and comment, and how to inform them of the academic format. They should know the components of a book review: copyright information, title of the book under review, author, main content of the book, strong points, and weak points of the book. We start the class by talking about students' reading experience of book reviews. To my surprise, many students have not had much experience, let alone knowing the format of a book review, and they do not understand the importance of book reviews in their research work. So, this is a new experience for them. The book review we read in class is a review of two new Winston Churchill's biographies, which draw a portrait of a different Churchill: his gambling in his financial life and his career, and how this adventurous nature links with the important decisions he has made in his political career. In order to understand the originality of the two biographies, I ask students to draw a portrayal of Churchill through their previous readings. After a brainstorm, the picture of Churchill emerges, and we realize how biographers neglect the so call "negative" facet of Churchill. And the two biographies tend to complete the picture by focusing on the seemingly not positive images of Churchill. We comb through the review, and students are quick to identity the content and comments of the biographies. Then, they are required to write a book review, a book of their own choice in their major and share the valuations of the book with their classmates. This is a very rewarding experience. Students learn to be sensitive to the major points in the book and learn to summarize and comment.

Reading and writing help students to think critically and sort out their views. Students are encouraged to ask and answer challenging questions, so as to get out the comfort zone and fixed paradigm. The quality of our thoughts determines the quality of our life and that of what we produce, make, or build. Language acquisition is one aspect of English learning; what is more important is the cultivation of excellence in thought through a non-native language.

\section{Listening Activities}

Listening is a very important language input. Students are encouraged to listen to multifarious materials and develop critical analysis and synthesis abilities. The traditional teaching method in which students simply memorize or blindly accept information is discarded; instead, Language and Intercultural Critical Thinking 
Integrated Approach (LICTIA) is adopted to teach students to respond to alternative points of view and develop a solid foundation for making personal choices about what to accept and what to reject. Students are encouraged to challenge the fixed polarity of easy "either-or" choices. Intercultural perspective is vital for the development of students' cultural and global consciousness. Besides the training of listening skills, more attention is paid to the development of global competence and intercultural critical thinking, which are contextualized in English teaching.

In class, we focus on recent hot issues, intending to provoke students' interest in the world affair, cultural customs and clashes, and economic issues, etc. Students are encouraged to overcome egoism and cultural centralism and view things from different angles. For instance, we listen to materials concerning African Issue, Sino-US trade dispute, and the redemptive power of art. Our discussion of death penalty leads to the consideration of the role art plays in rehabilitating criminals. Many countries have adopted art programs in prisons to reform prisoners and achieved effective results. In order to let students understand the importance of art, we listen to a material entitled "Iraq's Children's Orchestra”, which talks about an art program initiated at the University of Basra's Faculty of Arts, aiming to keep children away from the language of violence, the language of exclusion and help kids heal and thrive through arts. The success of the project evidences that "Culture fights backwardness and extremism". After listening to the text, students provide more examples to show the power of art and are eager to talk about how art has transformed their lives in various ways.

African Issue is one of the focuses in listening class. It is a perfect case to see how our biased, partial, uninformed, or prejudiced thinking of Africa can be changed through critical thinking. For one, Africa has developed rather rapidly in the context of globalization and we need to get rid of the stereotypes associated with Africa, such as famine, social disorder, natural disasters, corruption, AIDS, and barbarism, and see Africa in its new image. For another, China's One Belt One Road Initiative places Africa in a strategical position in Sino-African relations and more efforts are made on both sides to enhance cooperation. The 2018 Beijing Summit of the Forum on China-African Cooperation (FOCAC) in Sept. 2018 and the setup of China-Africa Institute in 2019 offer a good opportunity for students to reevaluate this great continent. Under the topic of African Issue, students listen to a number of related materials including Ted speeches delivered at African forum, reports on extended US-African cooperation in the field of economy, agriculture and culture, China's increasing investment in Africa, etc. These materials help students to form a new picture of Africa and feel the impact of globalization. Living in an increasingly globalized world, it is important for students to form a world view, to step out of their narrow position and to understand the significance of building a community of shared future for mankind through dialog and cooperation in the manner of balance, multiculturalism, and equality.

Listening to these topics help students acquire critical thinking mode and intercultural communication and keep them informed of things vital to the development of human future and their value system and to the shaping of their behavior.

\section{Conclusion}

Gunn, Bertman, Burton, Ellis, and Virginia (1964) remarked that "the boundaries of English are continuously shifting, the content is growing, emphases are being modified, and broader relevancies are being established. Changes in means are inevitable” (p. 4). New challenges in English teaching require creativity and innovation in means. Language and Intercultural Critical Thinking Integrated Approach (LICTIA) is a response to the challenges. The emphasis is shifted from "reliance on the teacher's telling” to students' "discovering” 
(Gunn et al., 1964, p. 4). It integrates language skills with humanistic education.

Through years of English teaching by adopting LICTIA in English and non-English major classes, I have seen the big progress students have made in their language proficiency and intercultural critical thinking ability. Systematically cultivating excellence in thought is of utmost importance in English teaching, because shoddy thinking is costly, both in money in quality of life. Language learning does not only concern language proficiency, but more importantly, it concerns the way of thinking, both critically and interculturally. Students should learn to avoid "the disrespect for evidence, sloppy use of language, and substitution of hollering for reason”, which are common in our public discussion (Browne \& Keeley, 2007, p. viii). Teachers endeavor to build scaffold for students and let them develop autonomous learning, intercultural competence, critical thinking, and humanistic education. These are and will always be the goal of English teaching in China. The student's mind is not a storehouse to be filled but an instrument to be used.

\section{References}

Browne, M. N., \& Keeley, S. M. (2007). Asking the right questions: A guide to critical thinking. (8th ed.). New Jersey: Pearson Prentice Hall.

China's Standards of English Language Ability (CSE). (2016). Retrieved from http://cse.neea.edu.cn/res/ceedu/1811/6bdc26c323d188948fca8048833f151a.pdf

Gunn, M. A., Bertman, S., Burton, K., Ellis, D., \& Virginia, C. (1964). Creative approaches to the teaching of English. The Journal of Education, 147(2), 1-109.

“Intercultural Competence.” Retrieved from https://en.wikipedia.org/wiki/Intercultural_competence

Jewkes, W. T (1976). Mental fight: Northrop Frye and the teaching of literature. The Journal of General Education, 27(4), 281-298.

McClaran, N. (1978). Infusion of values eduction into contemporary American literature. The English Journal, 67(2), 56-60.

Paul, R., \& Elder, L. (2006). The miniature guide to critical thinking: Concepts and tools. The Foundation for Critical Thinking. Retrieved from https://www.criticalthinking.org/files/Concepts_Tools.pdf

Sun, Y. Z. (2017). On liberal English education. Foreign Language Teaching and Research, 49(6), 859-870.

UNESCO. (2001). Universal declaration on cultural diversity. Retrieved from http://www.unesco.org/new/fileadmin/MULTIMEDIA/HQ/CLT/pdf/5_Cultural_Diversity_EN.pdf

Wen, Q. F. (2015). Developing a theoretical system of production-oriented approach in language teaching. Foreign Language Teaching and Research, 47(4), 547-558. 